\title{
Aplikasi Pestisida Nabati Umbi Gadung (Dioscorea hispida) untuk Mengendalikan Hama Ulat Grayak (Spodoptera frugiperda) pada Tanaman Jagung (Zea mays) di Laboratorium Pengamatan Hama dan Penyakit Tanaman (LPHP) Banyumas
}

\author{
Application of Vegetable Pesticides for Indian Three-Leaved Yam (Dioscorea hispida) to \\ Control Caterpillars Pest (Spodoptera frugiperda) on Corn Plants (Zea mays) at the \\ Laboratory for Pests and Plant Diseases Observation (Lphp) Banyumas
}

\author{
Eka Wihartati ${ }^{1}$, Arif Prashadi Santosa ${ }^{2}$, Ardiana Kartika $\mathbf{B}^{\mathbf{3}}$ \\ ${ }^{1,2,3}$ Program Studi Agroteknologi Fakultas Pertanian dan Perikanan \\ Universitas Muhammadiyah Purwokerto
}

\begin{tabular}{l} 
ARTICLE INFO \\
\hline Article history: \\
DOI: \\
$\underline{\text { 10.30595/pspfs.v2i.189 }}$
\end{tabular}

Submitted:

July 29, 2021

Accepted:

Sept 10, 2021

Published:

Nov 10, 2021

\section{Keywords:}

Corn, Pests, Grayak Caterpillars (Spodoptera Frugiperda), Vegetable Pesticides, Gadung Tubers, Boiling, Blending

\begin{abstract}
One of the pests that attack corn plants in Banyumas is the armyworm pest (Spodoptera frugiperda) which has been endemic since early 2019. This pest can cause damage to up to $70 \%$ of the total land area of the corn crop. Generally, pest control is carried out using chemical pesticides which have a negative impact on the environment and health. Therefore, to overcome these negative impacts it is necessary to do better control such as control using vegetable pesticides or biopesticides. One of the plants that can be used as vegetable pesticides is the gadung tuber which contains diosgenin, steroid, saponin, alcohol, and phenol compounds. This study aims to determine the difference in the effectiveness of the vegetable pesticides of the gadung tubers which were extracted using two different methods, namely by blending and boiling. The resulting vegetable pesticides were applied to 25 samples of the pest Spodoptera frugiperda. The method of analysis used a qualitative descriptive method. The results showed that after the application of vegetable pesticides twice the samples of the caterpillars used were dead, which was indicated by the visual death appearance of Spodoptera frugiperda where the body turned stiff and secreted fluid, the color of the body turned blackish brown (burnt). The difference in the effectiveness of the results of the application of vegetable pesticides was seen in the mortality rate of caterpillars where for the caterpillars that were applied with boiling of 25 samples, 12 caterpillars that died on the second day, the third day 5 , the fourth day 4 caterpillars and the fifth day 4 caterpillars. Meanwhile, for the death rate of caterpillars that were applied with blending of 25 samples, the caterpillars that died on the second day were 10 , the third day 7 , the fourth day 6 , and the fifth day as many as 2 caterpillars. The application of both gadung tuber vegetable pesticides made by blending and boiling is considered equally effective in controlling armyworm pests but seen from the faster mortality rate using vegetable pesticides made by blending.
\end{abstract}

This work is licensed under a Creative Commons Attribution 4.0 International License.

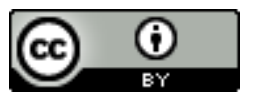

Proceedings homepage: https://conferenceproceedings.ump.ac.id/index.php/pspfs/issue/view/9 


\section{Corresponding Author:}

Eka Wihartati

Program Studi Agroteknologi Fakultas Pertanian dan Perikanan

Universitas Muhammadiyah Purwokerto

Email: ekawihartati36118@gmail.com

\section{PENDAHULUAN}

Saat ini diperkirakan untuk areal pertanaman jagung di lahan sawah irigasi serta sawah tadah hujan meningkat masing-masing 10-15\% dan 20-30\% utamanya di daerah produksi jagung komersial. Kedudukan jagung sebagai sumber pangan utama memiliki peluang yang relatif tinggi untuk dikembangkan sebagai bahan baku industry pengolahan pangan (Wartapa et al., 2019). Selain untuk sumber utama karbohidrat serta protein sesudah beras, jagung adalah salah satu serealia yang strategis sera memiliki nilai ekonomi yang dapat dijadikan sebagai sumber pakan (Wahyudin et al., 2016). Namun, kebutuhan jagung untuk pangan serta pakan baik kualitas maupun kuantitas belum terpenuhi sehingga masih terdapat impor dari negara lain. Rendahnya hasil jagung disebabkan oleh berbagai factor diantaranya yaitu faktor fisik (iklim, jenis tanah serta lahan) kemudian faktor biologis (varietas, hama, penyakit serta gulma), dan juga faktor sosial ekonomi. Menurut Baco dan Tandiabang (1988) dalam Surtikanti (2011) lebih dari 50 spesies serangga sudah ditemukan yang bisa menyerang tanaman jagung di Indonesia. Hama dan penyakit merupakan salah satu kendala didalam peningkatan produksi jagung.

Hama adalah salah satu masalah didalam budidaya jagung tersebut. Dan salah satu hama yang kerap mengganggu pertanian di Negara Indonesia, termasuk dalam pertanaman jagung adalah hama ulat grayak. Saat ini terdapat jenis ulat grayak baru yang tengah mewabah di dunia yaitu Fall Armyworm (FAW) atau Spodoptera frugiperda. Hama tersebut termasuk ke dalam ordo Lepidoptera, family Noctuidae. Hama S. frugiperda menyerang tanaman pangan seperti jagung, padi, serta gandum. Hama tersebut sudah mewabah dalam waktu yang cepat dari benua Amerika pada tahun 2016, masuk ke benua Afrika dan menyebar di wilayah Asia hingga ke Thailand pada tahun 2018 (Maharani, 2019). Ulat grayak jagung atau Spodoptera frugiperda J.E. Smith adalah serangga invasif yang sudah menjadi hama pada tanaman jagung (Zea mays) di Indonesia. Serangga yang berasal dari Amerika dan sudah menyebar di berbagai negara. Pada awal tahun 2019, hama ini ditemukan pada tanaman jagung di daerah Sumatera. Hama ini menyerang titik tumbuh tanaman yang bisa mengakibatkan kegagalan pembetukan pucuk/daun muda tanaman. Larva S. frugiperda mempunyai kemampuan makan yang tinggi. Larva akan masuk ke dalam bagian tanaman kemudian aktif makan disana, sehingga ketika populasi masih sedikit akan sulit untuk dideteksi. Imagonya merupakan penerbang yang kuat serta mempunyai daya jelajah yang tinggi (Maharani dkk, 2019).

Pengendalian hama yang umum dilakukan adalah insektisida kimia dengan frekuensi penyemprotan yang tinggi. Namun, insektisida kimia memiliki dampak negatif bagi kesehatan yaitu terganggunya beberapa organ tubuh seperti perut, jantung, ginjal, hati, mata, pencernaan, bahkan bisa berdampak fatal yaitu kematian. Penggunaan insektisida sintesis juga bisa merusak lingkungan seperti kerusakan tanah, air, tumbuhan serta merusak rantai makanan dalam suatu ekosistem (Muhidin dkk, 2020).

Solusi atas dampak negatif insektisida kimia adalah mencegah, mengurangi dan tidak menggunakan insektisida kimia namun beralih pada insektisida nabati. Insektisida nabati bisa berasal dari tanaman. Insektisida nabati adalah insektisida yang berasal dari tumbuhan. Banyaknya dampak negative yang muncul dikarenakan penggunaan pestisida kimia, sehingga mendorong pemerintah untuk fokus pada pemanfaatan macam-macam pestisida yang aman untuk lingkungan (Suhartini dkk, 2017). Oleh sebab itu, penggunaan biopestisida, khususnya yaitu pestisida nabati yang merupakan kearifan lokal bangsa Indonesia. Pemanfaatan pestisida nabati mendapatkan perhatian penting seiring dengan munculnya dampak negative penggunaan pestisida sintetis terhadap kesehatan serta lingkungan (Kardinan A., 2011).

Secara umum tumbuhan mampu menghasilkan metabolit sekunder sebagai upaya pertahanan diri terhadap serangan organisme pengganggu tumbuhan seperti hama tanaman. Insektisida nabati mempunyai keunggulan yaitu murah dan mudah dibuat sendiri, relatif aman untuk lingkungan, tidak meracuni tanaman, tidak menyebabkan resistensi terhadap hama, sesuai jika digabungkan dengan metode pengendalian lain serta menghasilkan produk yang sehat karena bebas residu insektisida kimia (Muhidin dkk, 2020).

Berdasarkan pada permasalahan mengenai pengendalian hama ulat grayak maka perlu dikendalikan dengan pengendalian yang ramah lingkungan seperti biopestisida. Tanaman yang dapat dibuat untuk biopestisida salah satunya adalah umbi gadung, sebab umbi gadung diketahui mengandung senyawa dioskorin, diosgenin, dan dioscin. Senyawa tersebut bersifat racun pada manusia karena bisa mengganggu syaraf yaitu pusing dan muntah bagi yang mengkonsumsi umbi tersebut. Senyawa racun tersebut akan didistribusikan ke seluruh organ tanaman sehingga berpotensi digunakan sebagai racun bagi hama tanaman. Ditinjau dari etnobotani maka umbi gadung dapat digunakan sebagai insektisida nabati (Muhidin dkk, 2020).

Proceedings homepage: https://conferenceproceedings.ump.ac.id/index.php/pspfs/issue/view/9 
Tanaman gadung (Dioscorea hispida dennst) merupakan tanaman tahunan yang berpotensi sebagai pestisida nabati, karena bagian umbi secara umum mengandung diosgenin, steroid saponin, alkohol dan fenol yang efektif untuk mengendalikan hama ulat grayak. Saponin bersifat racun saraf, racun perut dan antifeedan dan dapat mengendalikan hama tikus, ulat dan hama pengisap. Alkaloid mampu untuk menghambat pertumbuhan dan perkembangan jamur patogen. Tanin, sebagai astrigen yang dapat memperkeras kulit (Pu'u et al., 2013). Laboratorium Pengamatan Hama dan Penyakit Tanaman (LPHP) Kabupaten Banyumas memiliki konsep pengendalaian hama ulat grayak tanaman jagung secara terpadu yang tidak hanya mengandalkan insektisida kimia. Konsep tersebut sudah disosialisasikan kepada petani. Oleh karena itu, perlu dikaji lebih mendalam pengendalian hama ulat grayak tanaman jagung di kabupaten Banyumas terlebih dengan menggunakan pestisida nabati untuk mengendalikan hama ulat grayak.

\section{METODE PENELITIAN}

Lokasi

Penelitian dilaksanakan di Laboratorium Pengamatan Hama dan Penyakit Tanaman (LPHP) Kabupaten Banyumas.

\section{Waktu Penelitian}

Penelitian dilaksanakan pada tanggal 26 Januari sampai dengan 23 Februari 2021.

\section{Bahan dan Alat}

Bahan yang dibutuhkan dalam penelitian diantaranya yaitu umbi gadung, alkohol $70 \%$, air, ulat grayak (Spodoptera frugiperda), daun dan tanaman jagung. Sedangkan alat yaitu panci, kompor, blender, beaker glass, jerigen, saringan, sprayer, pisau, sarung tangan, botol, kertas koran, karet gelang, ember, gayung, timbangan, baskom, kotak tempat ulat, label, alat tulis.

Variabel yang Diamati frugiperda.

Variabel pengamatan yang diamati meliputi mortalitas larva dan kenampakan kematian larva S.

\section{Metode Analisis}

Metode analisis menggunakan metode deskriptif kualitatif.

\section{HASIL DAN PEMBAHASAN}

\section{Hasil Identifikasi Larva}

Hasil identifikasi larva yang ditemukan menunjukkan bahwa larva S. frugiperda telah menyerang tanaman jagung di sawah RT 02 RW 03 Desa Tinggarjaya Kecamatan Jatilawang. Karakteristik dari larva/ulat grayak (S. frugiperda) yang ditemukan yaitu kepala ulat ini berwarna gelap dan terdapat bentuk Y terbalik berwarna terang di bagian depan kepala (Maharani et al., 2019; Nadrawati et al., 2019; Sari, 2020). Hama ini juga memiliki empat buah pinacula membentuk segiempat pada abdomen segmen 8 (Lubis et al., 2020; Maharani et al., 2019). Bagian dorsalnya memiliki seta tunggal pada pinaculum (pinacula), dan berwarna gelap serta terdapat garis pada bagian atas tubuh (Maharani et al., 2019). Selain itu, hama ini juga memiliki pita tebal pada bagian lateral dan memiliki proleg pada abdomen (Lubis et al., 2020; Maharani et al., 2019).

\section{Pembuatan Pestisida Nabati Umbi Gadung}

Pada pembuatan pestisida nabati, umbi gadung yang digunakan berasal dari daerah Kabupaten Kebumen, Kecamatan Karanggayam yang telah berumur \pm 12 bulan. Dalam pembuatan pestisida umbi gadung, terdapat dua cara pembuatan yaitu pestisida umbi gadung dengan cara diblender atau direbus. Pembuatan pestisida umbi gadung dengan metode diblender berasal dari jurnal dan petunjuk teknis pembuatan pestisida nabati dari Balai Pengkajian Teknologi Pertanian (BPTP) Bengkulu sedangkan untuk pembuatan pestisida umbi gadung dengan cara perebusan merupakan metode yang di dapat dari Laboratorium PHPT Banyumas.

Dari kedua metode pembuatan yang telah dilakukan, terdapat perbedaan hasil ekstrak umbi gadung yang didapat. Perbedaan tersebut terdapat pada warna cairan yang dihasilkan, dimana ekstrak cairan dari umbi gadung yang direbus memiliki warna putih keruh sedangkan ekstrak cairan dari umbi gadung yang diblender berwarna putih kekuningan.

\section{Pengaplikasian Pestisida Nabati ke Larva S. frugiperda}

Aplikasi dilakukan dengan menempatkan ulat pada 2 buah kotak yang mana masing-masing kotak berisi 25 ulat dengan diberi makan berupa daun jagung. Kotak pertama digunakan untuk aplikasi pestisida nabati ekstrak umbi gadung yang direbus dan kotak kedua digunakan untuk aplikasi pestisida nabati ekstrak umbi gadung yang diblender. Aplikasi dilakukan dengan cara menyemprotkan larutan ekstrak umbi gadung secara merata keseluruh permukaan kotak (Pu'u \& Maria, 2013). Kemudian, pengamatan dilakukan setiap hari hingga 
hari ke-5 setelah pemberian pestisida. Pengaplikasian dilakukan sebanyak dua kali yaitu pada hari ke-1 dan hari ke-3 untuk masing-masing perlakuan. Ulat grayak tetap diberikan makanan berupa daun jagung disetiap harinya dan dilakukan pembersihan kotak dari kotoran. Aplikasi dilakukan pada pagi hari.

Mortalitas Larva Spodoptera frugiperda

\begin{tabular}{ccccc}
\hline \multirow{2}{*}{ Hari ke- } & \multicolumn{2}{c}{ Jumlah Sampel Ulat } & \multicolumn{2}{c}{ Jumlah Ulat Mati } \\
\cline { 2 - 5 } & Rebus & Blender & Rebus & Blender \\
\hline 1 & 25 & 25 & 0 & 0 \\
2 & 13 & 15 & 12 & 10 \\
3 & 8 & 8 & 5 & 7 \\
4 & 4 & 2 & 4 & 6 \\
5 & 0 & 0 & 4 & 2 \\
\hline
\end{tabular}

Data diatas merupakan hasil pengamatan terhadap kematian ulat grayak setelah disemprot dengan pestisida nabati umbi gadung. Umbi gadung yang direbus dan umbi gadung yang diblender sama-sama menunjukkan hasil yang efektif untuk mematikan ulat grayak. Hal ini ditunjukan dengan matinya semua ulat pada hari ke-5. Ada perbedaan jumlah kematian setiap harinya tetapi tidak terlalu signifikan.

Senyawa dioscorin yang terkandung dalam umbi gadung mempunyai efek insektisida terhadap ulat (Utami \& Haneda, 2012:216). Selain dioscorin dalam umbi gadung juga terdapat senyawa pahit saponin yang tidak disukai ulat grayak sehingga lebih efektif untuk mengendalikan hama ulat (Syafi'i, dkk. 2009:62). Senyawa saponin mempunyai efek menurunkan tegangan permukaan, sehingga merusak membran sel, menginaktifkan enzim sel dan merusak protein sel. Senyawa umbi gadung yang mempengaruhi mortalitas ulat grayak adalah diosgenin, senyawa ini mempengaruhi mortalitas ulat melalui sistem syaraf yang menyebabkan ulat grayak muntah-muntah, pusing sehingga ulat grayak lebih cepat mati (Butarbutar, dkk., 2013).

Pada umbi-umbian proses perebusan dapat mengurangi kadar sianida 60-90\% (Murdiana et al, 2000). Selain itu pemanasan dapat mengurangi kadar sianida umbi (Chukwuemeka, dalam Kumoro, dkk, 2011). Pemanasan memiliki dwifungsi, menginaktifkan enzim dan menguapkan HCN yang terbentuk karena senyawa ini sifatnya volatile. Pemanasan akan menyebabkan enzim b-glukosidase yang berada dalam umbi (sitoplasma selular) mengalami inaktif sehingga rantai enzimatis dapat diputus. Jika reaksi itu diputus, pembentukan sianohidrin dari glukosida sianogenik dan reaksi pembentukan HCN dari sianohidrin bisa dihindari (Pambayun, 2007). Dari pernyataan diatas dapat disimpulkan bahwa umbi gadung yang diblender lebih efektif digunakan dibandingkan menggunakan umbi gadung yang direbus terlebih dahulu.

Meskipun pemanasan dapat mengurangi kadar pestisida dalam umbi gadung, tetapi umbi gadung tersebut masih efektif untuk membunuh ulat grayak. Hal ini dikarenakan ulat grayak juga memiliki sifat kanibal. Pada saat penghitungan ulat yang mati ditemukan bahwa ada sebagian ulat yang mati tinggal setengah bagian tubuh saja. Hal tersebut diduga bahwa ulat yang hidup memakan ulat yang mati atau memakan sesama. Hal tersebut sesuai dengan pernyataan Sari (2020) yang menyatakan bahwa hama S. frugiperda bersifat kanibal, yakni memakan sesamanya. Ulat S. frugiperda selalu makan tanaman jagung di sepanjang waktu siang dan malam tak berhenti, hingga habis tanamannya.

\section{Kenampakan Kematian Larva Spodoptera frugiperda}

Kenampakan kematian visual pada ulat/larva Spodoptera frugiperda yaitu tubuhnya menjadi kaku, mengeluarkan cairan serta warna tubuh bagian luar berubah menjadi cokelat dan hitam (gosong). Sesuai dengan pernyataan Mutiara \& Novalia (2010) ulat yang mengalami kematian warnanya berubah menjadi coklat dan hitam. Seluruh bagian badan berubah tekstur dari yang semua kenyal ketika sebelum diberi perlakuan menjadi berair bahkan ada yang kering dan ulat tidak bergerak apabila disentuh. Selain mengalami perubahan dari segi warna dan tekstur, ulat grayak (Spodoptera frugiperda) yang mengalami kematian setelah diberi perlakuan juga mengalami perubahan bentuk badan dari yang semula panjang bulat, menjadi panjang gepeng. Hal ini dikarenakan ulat grayak (Spodoptera frugiperda) yang dalam keadaan hidup dan aktif mengalami perubahan penurunan nafsu makan. Ulat grayak (Spodoptera frugiperda) yang sekarat menunjukan perubahan perilaku dari yang semula aktif bergerak menjadi pasif tidak mau bergerak. Kemudian ulat cenderung mengkerutkan badannya, dan warnanya pun menjadi pucat. Adapun kenampakan larva S. Frugiperda sebelum dan sesudah pengaplikasian pestisida nabati umbi gadung dapat dilihat pada gambar dibawah ini. 

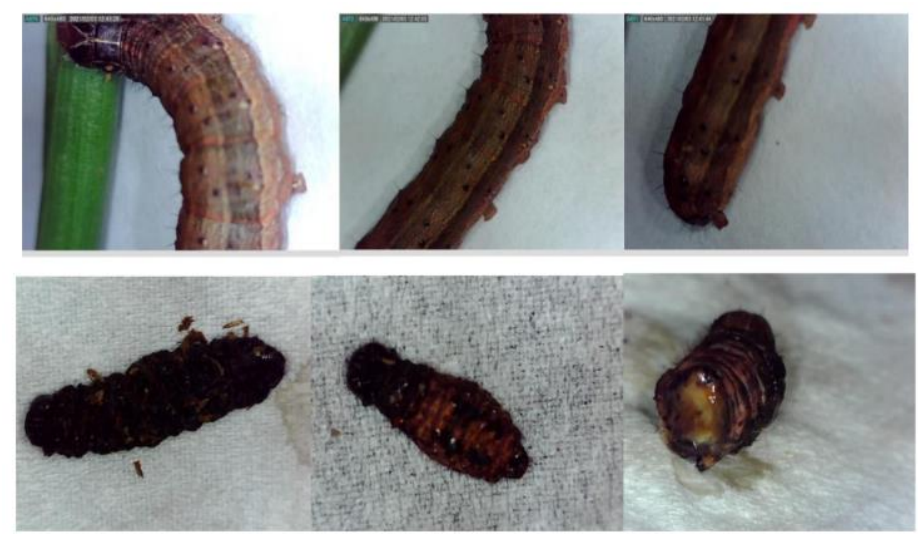

Kenampakan Larva S. frugiperda Sebelum dan Sesudah Pengaplikasian

Perubahan-perubahan itu diyakini terjadi karena adanya penyerapan insektisida nabati berupa senyawa dioscorin yang dikandung umbi gadung secara kontak. Penyerapan dioscorin secara kontak yang terjadi saat penyemprotan memungkinkan cairan insektisida mengenai permukaan tubuh S. frugiperda bagian dorsal dan masuk melalui pemukaan tubuh bagian kutikula yang tipis seperti perhubungan antar segmen. Penyerapan metabolit sekunder umbi gadung (Dioscorea hispida) melalui kutikula tersebutlah, yang menyebabkan ulat grayak (Spodoptera frugiperda) mengalami kematian (Afidah, dkk. 2014:47).

Mekanisme penyerapan dioscorin, selain melalui kulit juga melalui saluran pencernaan (Ningsih, dkk. 2013:35). Hal ini disebabkan karena dioscorin dapat menurunkan kemampuan dalam mencerna makanan dengan jalan menurunkan aktivitas enzim protease dan amilase yang berfungsi membantu sistem pencernaan, melalui makanan yang masuk kedalam saluran pencernaan (Mutiara \& Novalia, 2010:31). Makanan masuk ke saluran pencernaan bagian tengah (midgut) yang terdiri atas dua bagian yaitu kantung gastric yang mengeluarkan enzim pencernaan dan bagian ventrikulus. Saluran pencernaan bagian tengah merupakan organ utama pada pencernaan serangga, karena saluran pencernaan bagian ini merupakan organ penyerap nutrisi dan sekresi enzim-enzim. Apabila sekresi enzim terganggu maka proses pencernaan makanan dan metabolisme ulat grayak juga terganggu sehingga ulat akan kekurangan energi dan lama-kelamaan ulat kemudian mati (Ningsih, dkk. 2013:35). Selain itu untuk untuk diocorin dan senyawa-senyawa yang lain bisa mempengaruhi mortalitas ulat grayak karena senyawa aktif tersebut terakumulasi di dalam tubuh ulat grayak dan kemudian terdistribusikan ke seluruh tubuh melalui sistem peredaran darah, sehingga lebih cepat mengakibatkan kematian (Ningsih, dkk. 2013:35).

\section{KESIMPULAN}

Kesimpulan dari penelitian ini adalah sebagai berikut:

1. Pengaruh pengaplikasian pestisida nabati umbi gadung terhadap hama tanaman jagung dapat dilihat dari kenampakan kematian visual dari ulat/larva Spodoptera frugiperda dimana tubuhnya akan berubah menjadi kaku dan mengeluarkan cairan, warna tubuh bagian luar berubah menjadi cokelat dan hitam (gosong).

2. Pengaplikasi pestisida nabati umbi gadung yang disemprotkan ke ulat grayak (Spodoptera frugiperda) dapat dinilai efektif untuk mengendalikan hama ulat grayak baik pestisida nabati umbi gadung yang diblender maupun yang direbus. Dimana 2 kali pengaplikasian pestisida nabati umbi gadung sudah dapat membunuh semua sampel ulat.

\section{DAFTAR PUSTAKA}

Afidah, R. dkk. 2013. Pengaruh Kombinasi Filtrat Umbi Gadung, Daun Sirsak, dan Herba Anting-Anting terhadap mortalitas Larva Ordo Lepidoptera. Jurnal Lentera Bio. 3 (1), 45-49.

Butarbutar, R. dkk. Pengaruh Beberapa Jenis Pestisida Nabati untuk Mengendalikan Ulat Grayak Spodoptera litura (Lepidoptera: Noctuidae) Pada Tanaman Tembakau Deli Di Lapangan. Jurnal Online Agroekoteknologi. 1 (4), 1484-1494.

Kardinan, A. 2011. Penggunaan Pestisida Nabati untuk Kearifan Lokal pada Pengendalian Hama Tumbuhan Menuju Sistem Pertanian Organik. Jurnal Pengembangan Inovasi Pertanian, Vol. 4 No. 4: 262-274.

Kumoro, A. C., Retnowati, D. S., dan Budiyati, C. S. 2011. Removal of Cyanides from Gadung (Dioscorea hispida Dennst.) Tuber Chips using Leaching and Steaming Techniques. Journal of Applied Sciences Research, 7(12): 21402146, 2011 ISSN 1819-544X. 
Lubis, A. A. N., Ruly A., Bonny PW. S., Bonjok I., Dewi S., Irmansyah \& Dian H. 2020. Serangan Ulat Grayak Jagung (Spodoptera frugiperda) pada Tanaman Jagung di Desa Petir, Kecamatan Darmaga, Kabupatem Bogor dan Potensi Pengendaliannya Menggunakan Metarizhium Rileyi. Jurnal Pusat Inovasi Masyarakat, Vol 2 (6): 931-939. ISSN 2721-897X.

Maharani, Y., Vira K. D., Lindung T. P., Lilian R., Yusup H., dan Danar D. 2019. Cases of Fall Army Worm Spodoptera frugiperda J. E. Smith (Lepidoptera: Noctuidae) Attack on Maize in Bandung, Garut and Sumedang District, West Java. Jurnal Cropsaver, 2(1): 38-46. ISSN: 2621-5756.

Muhidin, Ruswadi M., \& Hasnelly. 2020. Pengaruh Insektisida Nabati Umbi Gadung terhadap Wereng Batang Cokelat (Nillavarpata lugens Stall) pada Tanaman Padi. Jurnal Ilmiah Respati, 11(1): 62-68.

Murdiana, A. 2000. Pengaruh Berbagai Cara Pengolahan untuk Mengurangi Sifat Goitrogenik Tiosianat pada Beberapa Bahan Makanan di Daerah Endemik Gondok. (Serial Online). http://digilib.litbang.depkes.go.id. (25 Maret 2021).

Mutiara, D. \& Novalia, N. 2010. Uji Toksisitas Akut Ekstrak Umbi Gadung (Discorea hispida Dennst) Terhadap Kematian Larva Spodoptera litura. Jurnal Sainmatika, 7 (2), 26-32.

Nadrawati, Sempurna G., \& Agustin Z. 2019. Identifikasi Hama Baru dan Musuh Alaminya pada Tanaman Jagung, di Kelurahan Sidomulyo, Kecamatan Seluma, Bengkulu. Laporan Penelitian. Bengkulu. Fakultas Pertanian, Universitas Bengkulu.

Ningsih, T.U. dkk. 2013. Pengaruh Filtrat Umbi Gadung, Daun Sirsak, dan Herba AntingAnting terhadap Mortalitas Larva Spodoptera litura. Jurnal Lentera Bio. 2 (1), 33-36.

Pambayun, R. 2007. Kiat Sukses Teknologi Pengolahan Umbi Gadung. Yogyakarta: Ardana Media.

Pu'u, Y. M. S. dan Maria A. M. 2013. Efektifitas Ekstrak Umbi Gadung (Dioscorea hispida) terhadap Hama Ulat Grayak (Spodoptera litura F.). Agrica, 6(2): 101-111. ISSN: 1979- 0368.

Sari, K. K. 2020. Viral Hama Invasif Ulat Grayak (Spodoptera frugiperda) Ancam Panen Jagung di Kabupaten Tanah Laut Kalsel. Proteksi Tanaman Tropika, Vol. 3(03): 244- 247. ISSN: 2685-8193.

Suhartini, Suryadarma, I., \& Budiwari. 2017. Pemanfaatan Pestisida Nabati Pada Pengendalian Hama Plutella xylostella Tanaman Sawi (Brassica juncea L.) Menuju Pertanian Ramah Lingkungan. J. Sains Dasar, 6(1): 36-43.

Surtikanti. 2011. Hama dan Penyakit Penting Tanaman Jagung dan Pengendaliannya. Seminar Nasional Serealia. Balai Penelitian Tanaman Serealia. Hal. 497-508.

Syafi'i. I. dkk. 2009. Detoksifikasi Umbi Gadung (Dioscorea hispida Dennts) dengan Pemanasan dan Pengasaman Pada Pembuatan Tepung. Jurnal Teknologi Pertanian, 10 (1), 62 - 68).

Utami, S. \& Haneda, N.F. 2012. Bioaktivitas Ekstrak Umbi Gadung dan Minyak Nyamplung Sebagai Pengendali Hama Ulat Kantong (Pteroma plagiophleps Hampson). Jurnal Penelitian Hutan Tanaman. 9 (4), 209-218.

Wahyudin, A., Ruminta, \& S. A. Nursaripah. 2016. Pertumbuhan dan Hasil Tanaman Jagung (Zea mays L.) Toleran Herbisida Akibat Pemberian Berbagai Dosis Herbisida Kalium Glifosat. Jurnal Kultivasi, 15(2): $86-91$.

Wartapa, A., M. Slamet, K. Ariwibowo, \& S. Hartati. 2019. Teknik Budidaya Jagung (Zea mays L.) untuk Meningkatkan Hasil. Jurnal Ilmu-ilmu Pertanian, 26(2): 1-13. 